\title{
PENGARUH STRATEGI REPOSITIONING HOLIDAY INN BANDUNG TERHADAP KEPERCAYAAN TAMU MEMBER
}

\author{
Gina Shesarria \\ Gitasiswhara \\ Manajemen Pemasaran Pariwisata FPIPS UPI
}

\begin{abstract}
Hospitality industry has three classifications of the National Chain Hotel, International Hotel Chain and hotels that are managed independently. International Hotel Chain is standing in Bandung one of them is the Holiday Inn. Holiday Inn Bandung is one of the four-star hotel which has the highest actual share best among customary international chain hotel in the city of Bandung. One of the guests that must be maintained is a guest member. The effort to maintain it is to make changes or repositioning. The purpose of this study was to obtain findings on repositioning strategies undertaken, the level of trust and influence of repositioning strategies undertaken Holiday Inn Bandung guest member of the trust. Repositioning strategy used theory is Muzellec \& Lambkin, whereas the theory of confidence used was Doney \& Canon. Objects in this study was the guest of a member who stays good corporate member guest and guest of individual members. Independent variable $(X)$ is a repositioning strategy that consists of three dimensions of brand logos, building renovation and staff performance. Dependent variable (Y), namely trust. This type of study is a descriptive verifikatif, and the method used is survey with stratified random sampling technique, the obtained sample size of 100 respondents to the division of 56 respondents for this type of corporate members and 44 guests respondents for this type of individual member guest. Techniques of data analysis and hypothesis test used is multiple regression. The results showed that the repositioning strategy did have an influence on trust. Dimensional result greatest value of the brand logo of amounting to 5.742, then the second highest value obtained through the staff performance of 5.363, while the building renovation is considered guest members have no influence because the guest member has not felt comfortable and familiar with the appearance and location of new facilities.
\end{abstract}

Keywords: Repositioning, Hotel, Trust.

\section{PENDAHULUAN}

\subsection{Latar Belakang Penelitian}

Fenomena yang terjadi pada industri perhotelan di Kota Bandung adalah berkembangnya hotel-hotel yang merupakan International Chain Hotel. Hotel-hotel yang berdiri di bawah manajemen perusahaan tersebut di dominasi oleh hotel-hotel bintang atas seperti bintang 4 dan bintang 5. Berikut merupakan data hotel-hotel Chain International yang terdapat di Kota Bandung Tahun 2010. Terdapat beberapa International Hotel Chain yang terdapat di Kota Bandung pada tahun 2010 diantaranya Novotel Bandung, Aston Hotel Bandung, Hilton Hotel Bandung, Hyatt Regency Bandung, Sheraton Hotel Bandung, Arion Swiss Bell Hotel dan Holiday Inn Bandung.

Holiday Inn Bandung merupakan salah satu hotel chain international yang di kelola oleh manajemen Intercontinental Hotels Group yang bekerja sama dengan PT. Sanbe Karya Persada. Hotel yang berdiri pada tahun 1997 ini mempunyai tagline hotel tersendiri yang disebut Great Hotels Guest Love yaitu hotel yang baik yang selalu dicintai oleh tamu.

Pada tahun 2010 terjadi penurunan, sehingga target hunian tidak tercapai. Diantara tamu yang menginap terdapat beberapa jenis tamu salah satunya tamu member. Berdasarkan data yang diperoleh dari sales marketing Holiday Inn Bandung Tahun 2011 jumlah tamu member yang menginap tahun 2009 sebesar 913 dengan perincian 561 untuk member corporate dan 352 untuk member individu, sedangkan pada tahun 2010 jumlah tamu member yang menginap mengalami penurunan menjadi 832 dengan perincian 469 untuk member corporate dan 363 untuk member individu. Hal ini menunjukan adanya penurunan pada kepercayaan menginap pada tamu member terhadap Holiday Inn Bandung. 
Strategi Holiday Inn Bandung yang telah disesuaikan oleh IHG yaitu perubahan serta penggantian beberapa aspek hotel. Strategi ini dijalankan oleh 3000 Holiday Inn di dunia, termasuk Holiday Inn Bandung. Holiday Inn harus tetap mempertahankan positioning citra di benak tamu member sebagai business-hotels yang selalu menjadi hotel yang terbaik dan dicintai tamu, positioning yang lebih kuat dapat mendeskripsikan nilai, selain itu dapat menjadi alat untuk mendeferensiasikan produk dari para pesaing.

Dalam istilah pemasaran, strategi ini disebut dengan Repositioning (Kartajaya 2004:129). Repositioning ini adalah strategi jangka panjang yang dilakukan oleh Holiday Inn, strategi ini dilakukan Holiday Inn sepanjang tahun 2010. Banyak aspek yang terkait dalam pelaksanaan strategi tersebut, diantaranya brand logo, buildings renovation dan staff performance (Muzzellec \& M.C. Lambkin 2006:806).

\subsection{Rumusan Masalah}

Berdasarkan latar belakang permasalahan yang telah dijelaskan di atas, maka dapat dirumuskan permasalahan pokok dalam penelitian ini adalah:

1. Bagaimana Strategi Repositioning yang dipersepsikan oleh tamu member Holiday Inn Bandung

2. Bagaimana gambaran tentang tingkat kepercayaan tamu member terhadap Holiday Inn Bandung

3. Sejauh mana pengaruh Strategi Repositioning Holiday Inn Bandung terhadap tingkat kepercayaan

\subsection{Tujuan Penelitian}

Tujuan penelitian ini adalah untuk mengetahui:

1. Strategi Repositioning yang dipersepsikan oleh tamu member Holiday Inn Bandung.

2. Tingkat kepercayaan tamu member terhadap Holiday Inn Bandung.

3. Pengaruh Strategi Repositioning Holiday Inn Bandung terhadap tingkat kepercayaan

\subsection{Kegunaan Penelitian}

a. Kegunaan Teoritis

Hasil penelitian ini diharapkan dapat memperluas ilmu tentang manajemen pemasaran pariwisata terutama dalam bidang hospitality and tourism marketing concept yang terdiri dari beberapa bahasan salah satunya tentang marketing strategy khususnya pada bagian segmenting, targeting dan positioning dari sebuah perusahaan serta diharapkan akan berkembang menjadi sebuah strategi repositioning dan dapat diimplementasikan terhadap teori kepercayaan, terutama dalam industri perhotelan. Selain itu pula dapat memperluas ilmu bagi pembaca maupun penulis sehingga dapat saling mengembangkan ilmu.

b. Kegunaan Praktis

Hasil penelitian ini pun diharapkan dapat menjadi tolak ukur bagi manajemen Holiday Inn Bandung dalam mempertahankan serta mengembangkan apa yang telah dimiliki setelah melakukan strategi repositioning khususnya dalam menjaga kepercayaan tamu member dengan terus memperhatikan strategistrategi yang dijalankan. Sehingga dapat dijadikan bahan informasi dan masukan agar Holiday Inn tetap menjadi hotel terbaik yang selalu dicintai oleh tamu.

\section{KERANGKA PEMIKIRAN DAN HIPOTESIS}

\subsection{Kerangka Pemikiran}

Pada strategi pemasaran, setiap perusahaan harus selalu mengetahui dan memahami hal-hal yang dibutuhkan serta diinginkan oleh konsumen. Menurut Kotler \& Bowen (2010:12) "Terdapat lima tujuan terhadap konsumen dan pasar yaitu need, wants and demands, marketing offerings (tangible product, service, and experiences), value and satisfaction, exchanges and relationship, markets". Berdasarkan penjelasan tersebut salah satu bentuk pemasaran yang diberikan terhadap konsumen dan pasar adalah dalam bentuk jasa. Selanjutnya menurut Kotler dan Bowen (2010:10) menyatakan bahwa, "Salah satu industri jasa terbesar di dunia yang sangat menguasai adalah pariwisata yaitu hospitality dan travel industri”.

Pariwisata menurut Hunzeieker adalah "Keseluruhan gejala-gejala yang ditimbulkan oleh perjalanan dan pendiaman orang-orang asing serta penyediaan tempat tinggal sementara, asal pendiaman itu tidak menetap dan memperoleh penghasilan dari aktivitas yang sementara". Terdapat empat karakteristik 
dalam sektor jasa dan hospitality menurut Kotler \& Bowen (2010:35) yaitu intangibility, insaparability, variability dan perishability. Salah satu strategi manajemen untuk bisnis jasa dan hospitality menurut Kotler \& Bowen (2010:39) adalah customer, accommodation and frontline service employee. Peningkatan kontribusi industri jasa diikuti dengan pertumbuhan jumlah usaha akomodasi.

Menurut Hermawan Kartajaya (2008:7), bahwa "Strategi marketing mempunyai tiga elemen penting yaitu Segmenting, Targeting dan Positioning". Segmenting menurut Kotler (2008:256) "a market segment consist of a large identifiable group within a market with similar wants, purchasing power, geogeraphical location, buying attitude or buying habits", dalam kebijaksanaan pemasaran perusahaan harus menetapkan strategi arah sasaran dan pemasarannya, apakah sasaran tersebut ditujukan keseluruh lapisan konsumen atau hanya menetapkan pada segmen pasar tertentu. Targeting menurut Fandy Tjiptono (2007:71) adalah "Proses, mengevaluasi, menyeleksi dan memilih satu atau beberapa segmen pasar yang akan dijadikan pasar sasaran. menurut Kotler (2009:308), "Positioning is the act of designing the companies offering and image to occupied a distinctive place in the target market. The goals is the located the brand in the mind of consumers to maximize the potential benefits to the firm". Menurut Hermawan Kartajaya (2008:57),"Positioning adalah bagaimana perusahaan membangun janji, kepercayaan dan keyakinan kepada konsumen".

Pada intinya positioning adalah menempatkan produk dan merek perusahaan di benak konsumen. Selain itu positioning adalah terciptanya proposisi nilai yang pas, yang menjadi alasan bagi konsumen untuk membeli. Positioning hakikatnya merupakan sebuah janji yang dibuat perusahaan kepada konsumennya. Kemampuan perusahaan untuk memenuhi janjinya merupakan bagian yang utama dari strategi. Karena alasan inilah positioning yang tepat merupakan hal yang penting bagi keberhasilan akhir produk, merek dan perusahaan. Keempat syarat membangun positioning itu diantaranya customer, company, competitor dan change.

Salah satu strategi yang banyak dilakukan oleh perusahaan untuk tetap dapat mengikuti permintaan dan perubahan yang terjadi pada pasar dan konsumen ada Repositioning, hal ini dapat berpengaruh terhadap kinerja perusahaan serta dapat membuat perusahaan tetap berada diantara pasar persaingan yang terus berkembang (Hermawan Kartajaya 2008:84). Terdapat beberapa kegiatan dalam repositioning menurut Muzzellec \& M.C.Lambkin (2006:806) yaitu "This may involve radical changes to the brand's logo, brand name, image, buildings renovation, staff performance, merchandise, marketing strategy and advertising themes".

Kata trust berasal dari bahasa Jerman "Trost" (Shaw 1997:27) yang berarti kenyamanan. Menurut teori TrustCommitment (Morgan dan Hunt 1994:129) kepercayaan adalah satu variable kunci untuk memelihara suatu hubungan jangka panjang, termasuk pada sebuah merek. Hubungan jangka panjang akan meningkatkan tingkat kepercayaan konsumen terhadap harapan yang akan diterima dari perusahaan.

Adapun faktor-fator karakteristik kepercayaan menurut Doney dan Cannon dalam Jurnal Tatang Kusmayadi (2007:166) antara lain:

1. Kredibilitas (Credibility)

Kredibilitas adalah alasan yang masuk akal untuk bisa dipercayai. Seseorang yang memiliki kredibilitas berarti dapat dipercayai karakter dan kemampuannya. Kredibilitas perusahaan akan selalu menjadi poin penting yang dipertanyakan baik oleh internal seperti karyawan dan manajemen, maupun oleh pihak luar seperti investor, partner dan konsumen. Kredibilitas perusahaan inilah yang menjadi dasar terbentuknya kepercayaan, adapun bagian-bagian dari kredibilitas yaitu:
a. Keahlian
Dalam membangun sistem dibutuhkan kehadiran orang yang kredibel menurut sistem yang dibangunnya. Menumbuhkan suatu kredibilitas seseorang atau sebuah perusahaan harus memiliki beberapa hal berikut ini, yaitu pengalaman, kualitas kerja, kecerdasan dan keterampilan.
b. Terpercaya 
Terpercaya adalah tidak adanya penolakan sehubungan dengan ide-ide yang dikeluarkannya. Terpercaya antara lain meliputi jujur dan adil.

c. Tepat waktu

Setiap perusahaan harus memenuhi janji terhadap setiap konsumen sesuai waktu yang sudah ditentukan sehingga konsumen akan tetap percaya terhadap perusahaan tersebut.

d. Keyakinan

Keyakinan yang tercipta akan membentuk kepercayaan, karena terdapat keyakinan terhadap keandalan, kemampuan, konsisten dalam memegang janji yang akan menciptakan nilai tambah dan kepuasan. Keyakinan dapat berasal dari komitmen total, tanggung jawab dan kemampuan kerja yang baik.

2. Komunikasi

Komunikasi merupakan media pembentuk kepercayaan. Keadaan yang sebenarnya, kejujuran dan keterbukaan adalah syarat utama dalam komunikasi untuk membentuk kepercayaan. Komunikasi yang dapat menghasilkan kepercayaan antara lain keterbukaan komunikasi serta kejujuran dan sikap apa adanya.

Kerangka pemikiran yang penulis ajukan untuk menunjukan adanya pengaruh antara strategi repositioning dengan menggunakan teori Muzellec \& Lambkin (2006:806) serta kepercayaan menggunakan teori Doney \& Cannon (1997:164) dapat digambarkan dalam suatu kerangka pemikiran sebagai berikut. 


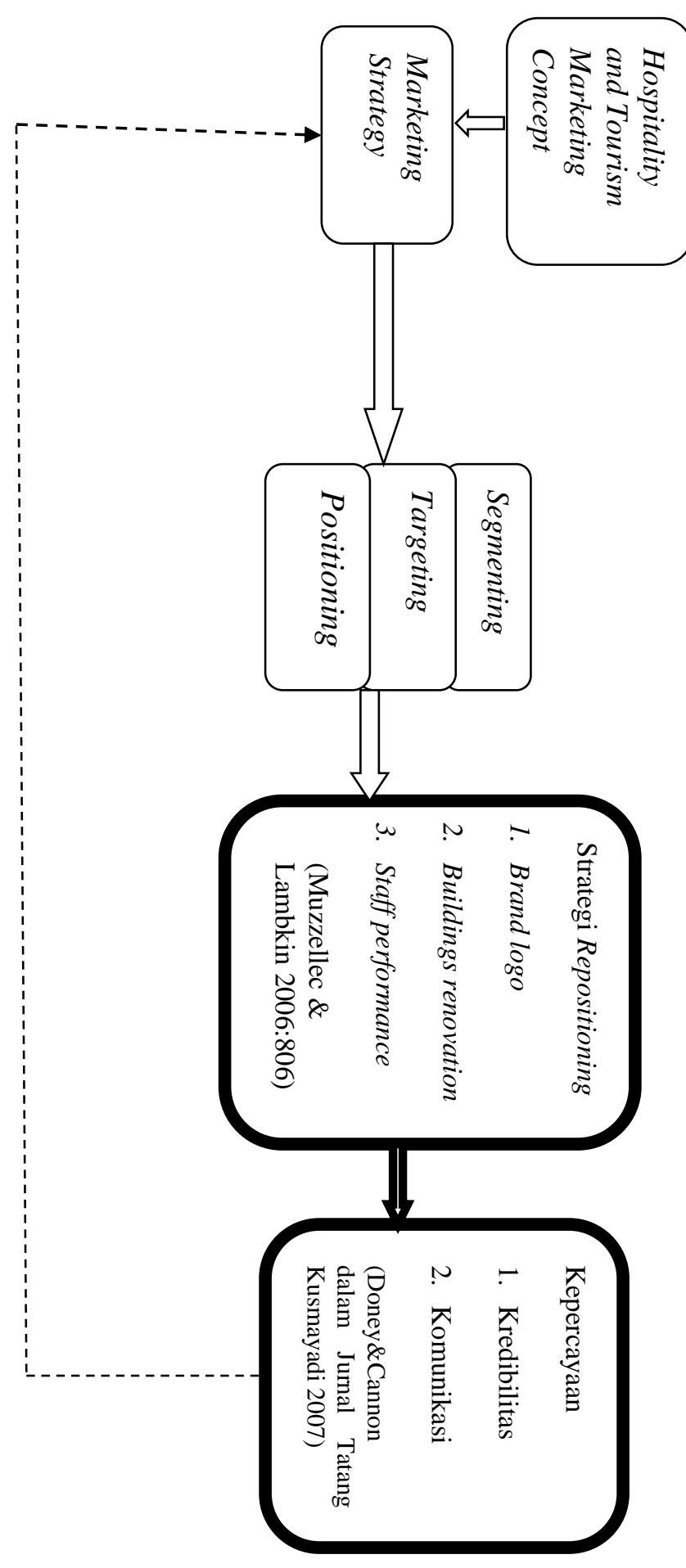

Gambar 2.1

Kerangka Pemikiran Pengaruh Strategi Repositioning Holiday Inn Bandung Terhadap Kepercayaan 


\subsection{Hipotesis Penelitian}

Hipotesis merupakan jawaban sementara terhadap rumusan masalah penelitian, di mana rumusan masalah penelitian telah dinyatakan dalam bentuk pernyataan (Sugiyono,2008:64). Dikatakan sementara karena pernyataan yang dikeluarkan hanya berdasarkan teori-teori yang mendukung bukan berdasarkan faktafakta yang nyata dari hasil pengumpulan data atau penelitian.

Peneliti dalam menyusun hipotesis didukung oleh beberapa premis sebagai berikut :
1. Menurut Kotler \& Keller (2009:288) "Repositioning adalah tindakan penempatan perusahaan atau memposisikan kembali dirinya dalam ingatan konsumen".

2. Pernyataan Hermawan Kartajaya (2008:57), "Repositioning adalah bagaimana perusahaan membangun janji, kepercayaan dan keyakinan kepada konsumen serta positioning menjadi penentu penting bagi konsumen pada saat memutuskan untuk membeli”.

3. Pernyataan menurut Raisa Yakimov and Michael Beverland dalam jurnalnya (2006), "Successful brand management firms place the brand at the centre of their organisation and strategy, and build integrated strategies to continually support this. These strategies enable the firm to connect to the marketplace, and gain market based information to ensure ongoing relevance, without damaging the brand's core identity".

\section{METODE PENELITIAN}

\subsection{Objek Penelitian}

Objek Penelitian yang menjadi variabel bebas atau independent adalah Strategi Repositioning dan yang menjadi variabel dependent atau variabel terikat adalah Kepercayaan. Unit analisis dari penelitian ini adalah tamu member yang menginap di Holiday Inn Bandung. Berdasarkan waktu penelitian yang dilaksanakan pada waktu kurang dari satu tahun yaitu mulai dari bulan Maret 2011 sampai dengan bulan Desember 2011, maka metode penelitian yang digunakan adalah metode cross sectional.

\subsection{Metode Penelitian}

3.2.1 Jenis Penelitian dan Metode yang Digunakan

Berdasarkan variabel-variabel yang diteliti maka jenis penelitian ini adalah penelitian deskriptif dan verifikatif. Menurut pendapat Sugiyono (2010:11) penelitian deskriptif merupakan penelitian yang bertujuan untuk memberikan gambaran dan nilai dari variabel penelitian. Melalui jenis penelitian deskriptif maka dapat diperoleh gambaran tentang strategi repositioning dengan indikator brand logo $\left(\mathrm{X}_{1}\right)$, buildings renovation $\left(\mathrm{X}_{2}\right)$ dan staff performance $\left(\mathrm{X}_{3}\right)$, sedangkan kepercayaan sebagai variabel terikat (Y). Sedangkan jenis penelitian verifikatif yaitu menguji kebenaran suatu hipotesis yang dilakukan melalui pengumpulan data di lapangan, datpenelitian verifikatif dimaksudkan untuk mengetahui pengaruh Strategy Repositioning Holiday Inn Bandung terhadap kepercayaan. Berdasarkan jenis penelitian di atas yaitu penelitian deskriptif dan verifikatif maka metode yang digunakan adalah explanatory survey.

\subsection{Operasionalisasi Variabel}

Operasionalisasi variabel adalah merupakan kegiatan mengurai variabel menjadi sejumlah variabel operasional atau variabel empiris (indikator, item) yang merujuk langsung pada hal-hal yang dapat diamati atau diukur.

Variabel-variabel yang akan diteliti adalah variabel strategi repositioning untuk variabel $\mathrm{X}$ dengan dimensi Brand logo, Buildings renovation dan Staff performance. Kepercayaan sebagai variabel Y dengan dimensi Kredibilitas dan Komunikasi. Penelitian ini menggunakan skala ordinal dikarenakan data yang ada pada penelitian ini merupakan data ordinal. Skala ordinal merupakan suatu skala dimana data ordinal adalah data yang berjenjang atau berbentuk peringkat. Secara lebih rinci operasionalisasi masing-masing variabel itu dapat terlihat dalam Tabel 3.1. 
Tabel 3.1

OPERASIONALISASI VARIABEL

\begin{tabular}{|c|c|c|c|c|c|}
\hline $\begin{array}{c}\text { Variabel/Sub } \\
\text { Variabel }\end{array}$ & Konsep & Indikator & Ukuran & Skala & $\begin{array}{l}\text { No. } \\
\text { Item }\end{array}$ \\
\hline 1 & 2 & 3 & 4 & 5 & 6 \\
\hline $\begin{array}{l}\text { Repositioning } \\
\text { (X) }\end{array}$ & $\begin{array}{l}\text { Repositioning adalah } \\
\text { penciptaan nama baru, } \\
\text { istilah, staf, simbol,desain } \\
\text { atau kombinasi dari mereka } \\
\text { untuk merek mapan dengan } \\
\text { tujuan mengembangkan posi } \\
\text { si (baru) dibedakan } \\
\text { dalam pikiran dan pemangku } \\
\text { kepentingan pesaing, jauh } \\
\text { dari hanya perubahanidentita } \\
\text { s visual, reposisi harus } \\
\text { menjadi bagian dari strategi } \\
\text { merek secara } \\
\text { keseluruhan untuk } \\
\text { produk atau jasa } \\
\text { (Muzzellec\&Lambkin } \\
\text { 2006:805) }\end{array}$ & $\begin{array}{l}\text { Keterlibatan } \\
\text { Repositioning } \\
\text { dalam } \\
\text { peningkatan } \\
\text { keputusan } \\
\text { menginap }\end{array}$ & & & \\
\hline $\begin{array}{l}\text { Brand Logo } \\
\left(\mathbb{Z}_{1}\right)\end{array}$ & $\begin{array}{l}\text { Cap dagang atau merek dari } \\
\text { produk, perusahaan, } \\
\text { organisasi atau lembaga } \\
\text { untuk keperluan komunikasi, } \\
\text { perdagangan dan } \\
\text { perlindungan hukum. } \\
\text { (Muzzellec \& Lambkin } \\
\text { 2006:806) }\end{array}$ & $\begin{array}{l}\text { - Warna } \\
\text { logo }\end{array}$ & $\begin{array}{l}\text { - Tingkat } \\
\text { kemenar } \\
\text { ikan } \\
\text { Warna } \\
\text { logo } \\
\text { sebelum } \\
\text { perubah } \\
\text { an yaitu } \\
\text { hijau } \\
\text { tua, } \\
\text { putih, } \\
\text { kuning } \\
\text { dan abu- } \\
\text { abu } \\
\text { dibandin } \\
\text { gkan } \\
\text { dengan } \\
\text { sesudah } \\
\text { perubah } \\
\text { an yaitu } \\
\text { hijau } \\
\text { muda } \\
\text { dan } \\
\text { putih } \\
\text { (Sebelu } \\
\text { m dan } \\
\text { Sesudah } \\
\text { ) } \\
\text { Tingkat } \\
\text { kemenar } \\
\text { ikan }\end{array}$ & - Ordinal & $\begin{array}{l}\text { III.A. } \\
1 \\
\\
\text { III.A. } \\
\\
\\
\text { III.A. } \\
3\end{array}$ \\
\hline
\end{tabular}

Tourism and Hospitality Essentials (THE) Journal, Vol.II, No.2, 2012 - 345 
Gina Shesarria, Gitasiswhara

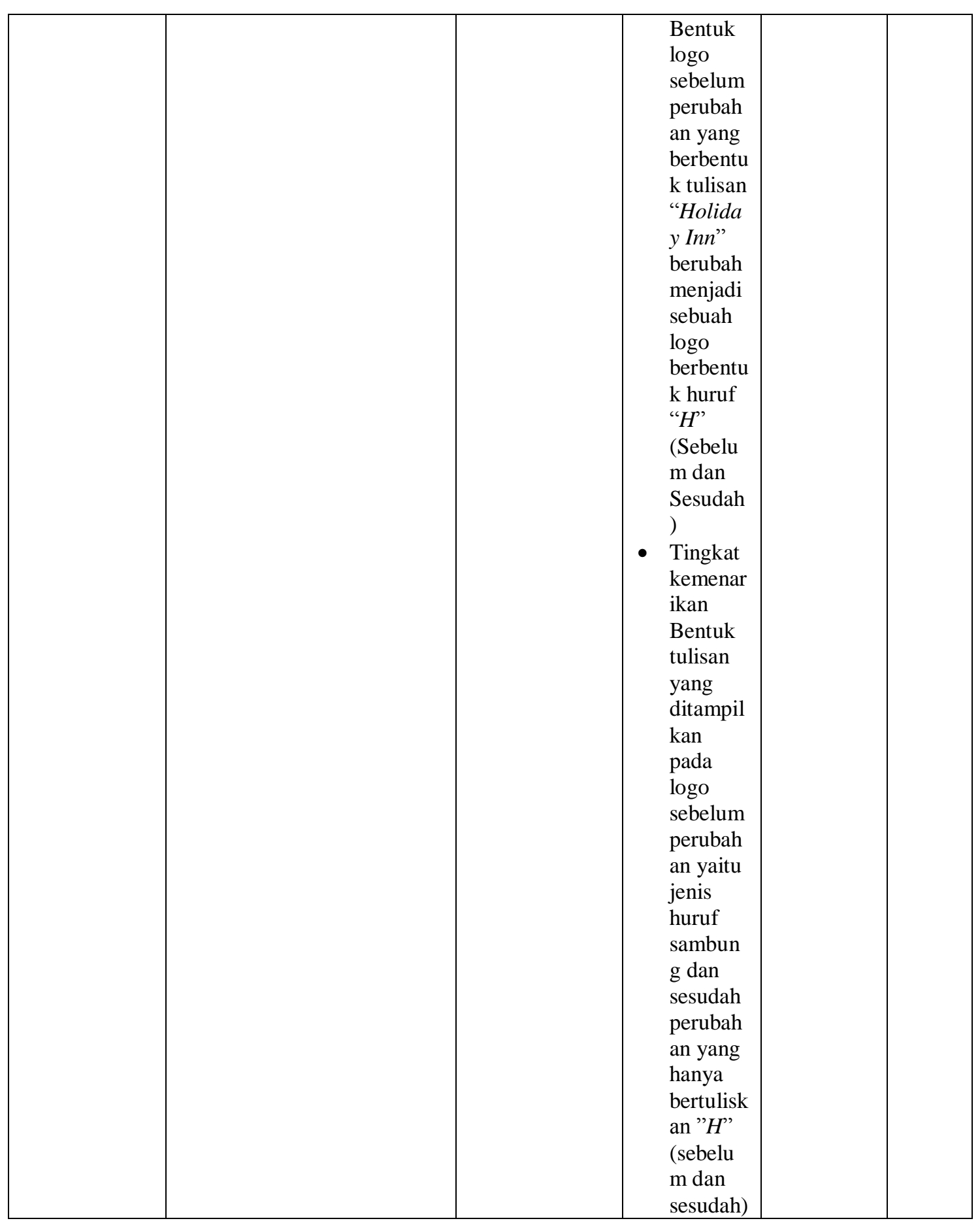

Tourism and Hospitality Essentials (THE) Journal, Vol.II, No.2, 2012 -346 


\begin{tabular}{|c|c|c|c|c|c|}
\hline $\begin{array}{l}\text { Building } \\
\text { Renovation } \\
\left(\mathcal{X}_{2}\right)\end{array}$ & $\begin{array}{l}\text { Perubahan suasana yang } \\
\text { dilakukan perusahaan untuk } \\
\text { menciptakan ciri yang sesuai } \\
\text { dengan tujuan perusahaan } \\
\text { (Muzzellec \& Lambkin } \\
\text { 2006:807) }\end{array}$ & $\begin{array}{l}\text { - Ketepatan } \\
\text { penambaha } \\
\text { n kamar }\end{array}$ & 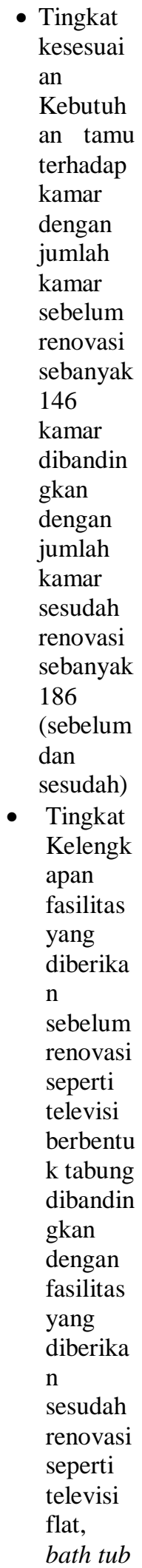 & - Ordinal & $\begin{array}{l}\text { III.B. } \\
2\end{array}$ \\
\hline
\end{tabular}

Tourism and Hospitality Essentials (THE) Journal, Vol.II, No.2, 2012 - 347 


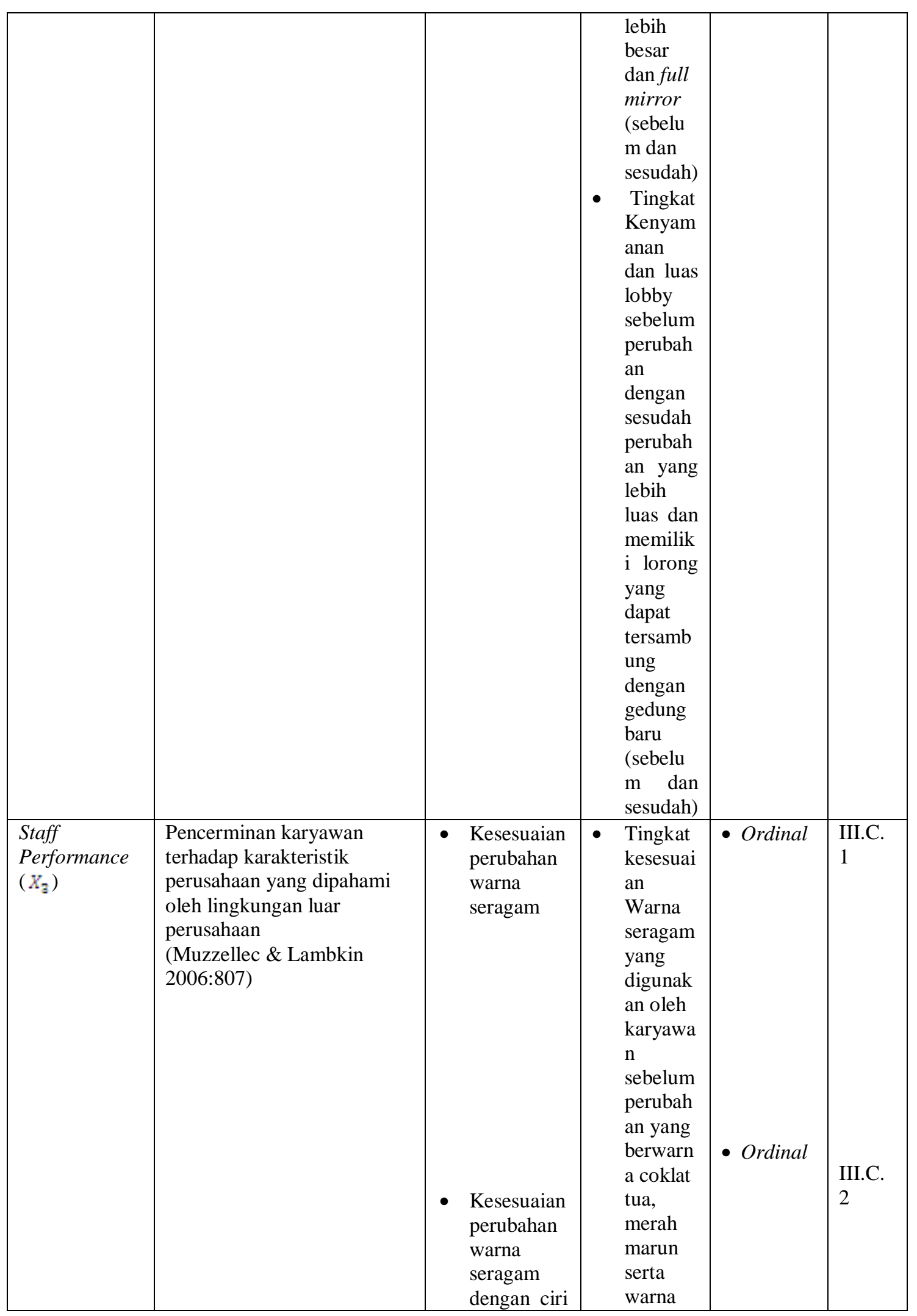

Tourism and Hospitality Essentials (THE) Journal, Vol.II, No.2, 2012 -348 


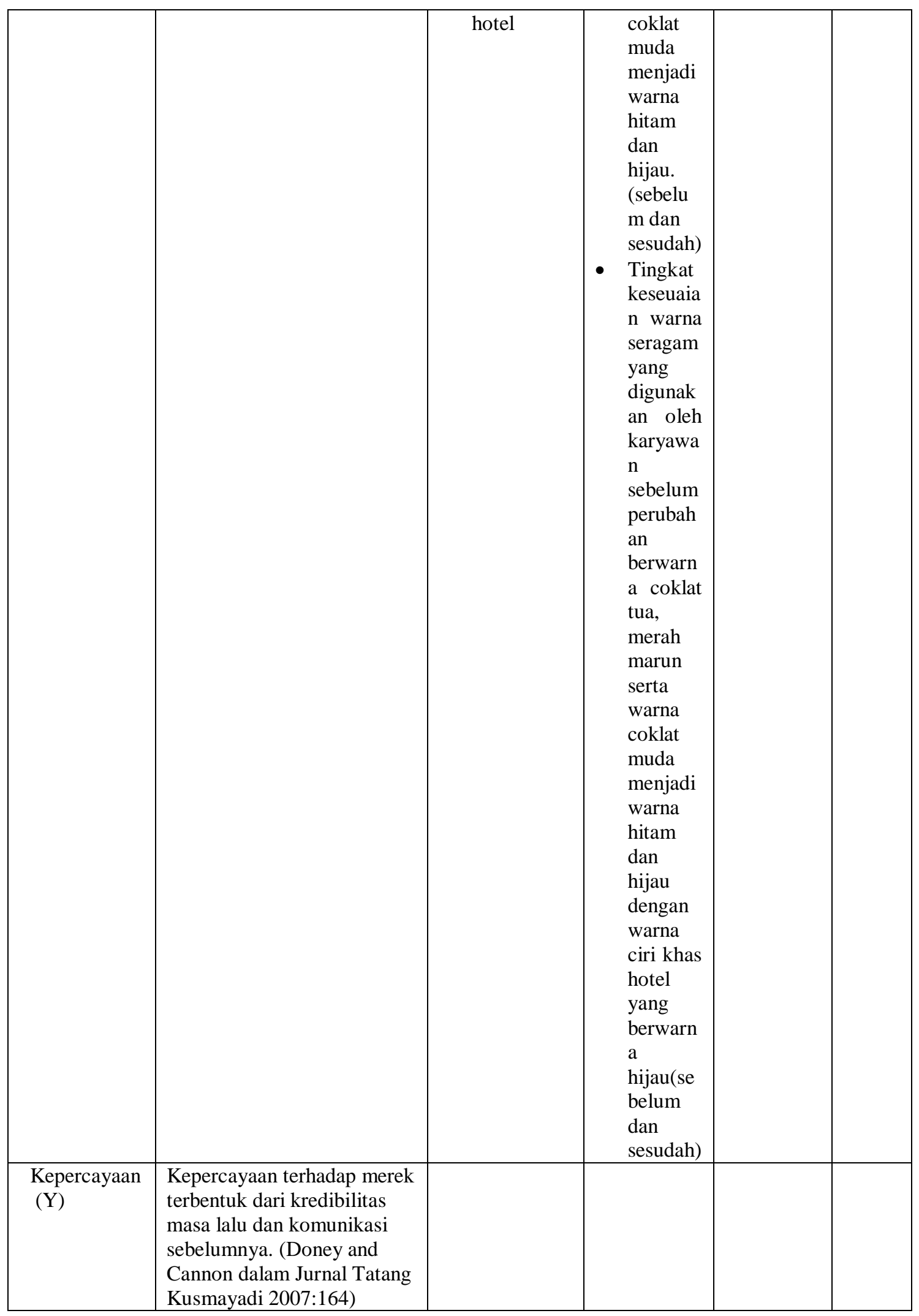

Tourism and Hospitality Essentials (THE) Journal, Vol.II, No.2, 2012 - 349 


\begin{tabular}{|c|c|c|c|c|c|}
\hline Kredibilitas $\left(\mathrm{Y}_{1}\right.$ & $\begin{array}{l}\text { Kredibilitas adalah alasan } \\
\text { yang masuk akal untuk bisa } \\
\text { dipercayai. Seseorang yang } \\
\text { memiliki kredibilitas berarti } \\
\text { dapat dipercayai karakter } \\
\text { dan kemampuannya. } \\
\text { (Doney and Cannon dalam } \\
\text { Jurnal Tatang Kusmayadi } \\
\text { 2007:166) }\end{array}$ & $\begin{array}{l}\text { - Kredibilitas } \\
\text { terhadap } \\
\text { fasilitas } \\
\text { utama } \\
\\
\text { - Kredibilitas } \\
\text { terhadap } \\
\text { fasilitas } \\
\text { penunjang } \\
\\
\text { - Kredibilitas } \\
\text { terhadap } \\
\text { pelayanan } \\
\text { awal } \\
\text { Kredibilitas } \\
\text { terhadap } \\
\text { citra } \\
\text { Holiday Inn } \\
\text { Bandung }\end{array}$ & $\begin{array}{l}\text { - Tingkat } \\
\text { keperca } \\
\text { yaan } \\
\text { Kredibil } \\
\text { itas dari } \\
\text { fasilitas } \\
\text { yang } \\
\text { diberika } \\
\text { n seperti } \\
\text { kamar } \\
\text { dan } \\
\text { restoran } \\
\text { (sebelu } \\
\text { m dan } \\
\text { sesudah } \\
\text { ) } \\
\text { - Tingkat } \\
\text { keperca } \\
\text { yaan } \\
\text { Kredibil } \\
\text { itas dari } \\
\text { fasilitas } \\
\text { penunja } \\
\text { ng } \\
\text { lainnya } \\
\text { seperti } \\
\text { bar, } \\
\text { ballroo } \\
\text { m dan } \\
\text { SPA } \\
\text { (sebelu } \\
\text { m dan } \\
\text { sesudah } \\
\text { ) Tingkat } \\
\text { keperca } \\
\text { yaan } \\
\text { Kredibil } \\
\text { itas dari } \\
\text { pelayan } \\
\text { an yang } \\
\text { diberika } \\
\text { n seperti } \\
\text { pelayan } \\
\text { an } \\
\text { reservas } \\
\text { i dan } \\
\text { pelayan } \\
\text { an } \\
\text { registras } \\
\text { i kamar } \\
\text { (sebelu } \\
\text { m dan }\end{array}$ & $\begin{array}{l}\text { - Ordinal } \\
\text { - Ordinal }\end{array}$ & $\begin{array}{l}\text { IV.A. } \\
3\end{array}$ \\
\hline
\end{tabular}

Tourism and Hospitality Essentials (THE) Journal, Vol.II, No.2, 2012 -350 


\begin{tabular}{|c|c|c|c|c|c|}
\hline$\left(\mathrm{Y}_{2}\right)$ & $\begin{array}{l}\text { media pembentuk } \\
\text { kepercayaan. Keadaan yang } \\
\text { sebenarnya, kejujuran dan } \\
\text { keterbukaan adalah syarat } \\
\text { utama dalam komunikasi } \\
\text { untuk membentuk } \\
\text { kepercayaan. } \\
\text { (Doney and Cannon dalam } \\
\text { Jurnal Tatang Kusmayadi } \\
\text { 2007:167) }\end{array}$ & $\begin{array}{l}\text { - Keyakinan } \\
\text { pelayanan } \\
\text { dan } \\
\text { tanggung } \\
\text { jawab } \\
\\
\text { - Komunikasi } \\
\text { penjelasan } \\
\text { fasilitas } \\
\\
\\
\text { - Komunikasi } \\
\text { penjelasan } \\
\text { saat } \\
\text { handling } \\
\text { complain }\end{array}$ & $\begin{array}{l}\text { sesudah } \\
\text { - Tingkat } \\
\text { keperca } \\
\text { yaan } \\
\text { Kredibil } \\
\text { itas dari } \\
\text { pelayan } \\
\text { an } \\
\text { tambaha } \\
\text { n yang } \\
\text { diberika } \\
\text { n seperti } \\
\text { pelayan } \\
\text { an } \\
\text { restoran } \\
\text { dan } \\
\text { pelayan } \\
\text { an } \\
\text { kamar } \\
\text { (sebelu } \\
\text { m dan } \\
\text { sesudah } \\
\text { ) } \\
\text { Tingkat } \\
\text { keperca } \\
\text { yaan } \\
\text { Kredibil } \\
\text { itas citra } \\
\text { Holiday } \\
\text { Inn } \\
\text { Bandun } \\
\text { g } \\
\text { sebagai } \\
\text { hotel } \\
\text { bisnis } \\
\text { (sebelu } \\
\text { m dan } \\
\text { sesudah } \\
\text { ) } \\
\text { - Tingkat } \\
\text { keperca } \\
\text { yaan } \\
\text { Keyakin } \\
\text { an } \\
\text { pelayan } \\
\text { an dan } \\
\text { tanggun } \\
\text { g jawab } \\
\text { yang } \\
\text { diberika } \\
\text { kepada }\end{array}$ & $\begin{array}{l}\text { - Ordinal } \\
\text { - Ordinal }\end{array}$ & $\begin{array}{l}\text { IV.A. } \\
7 \\
\\
\text { IV.A. } \\
8\end{array}$ \\
\hline
\end{tabular}

Tourism and Hospitality Essentials (THE) Journal, Vol.II, No.2, 2012 - 351 


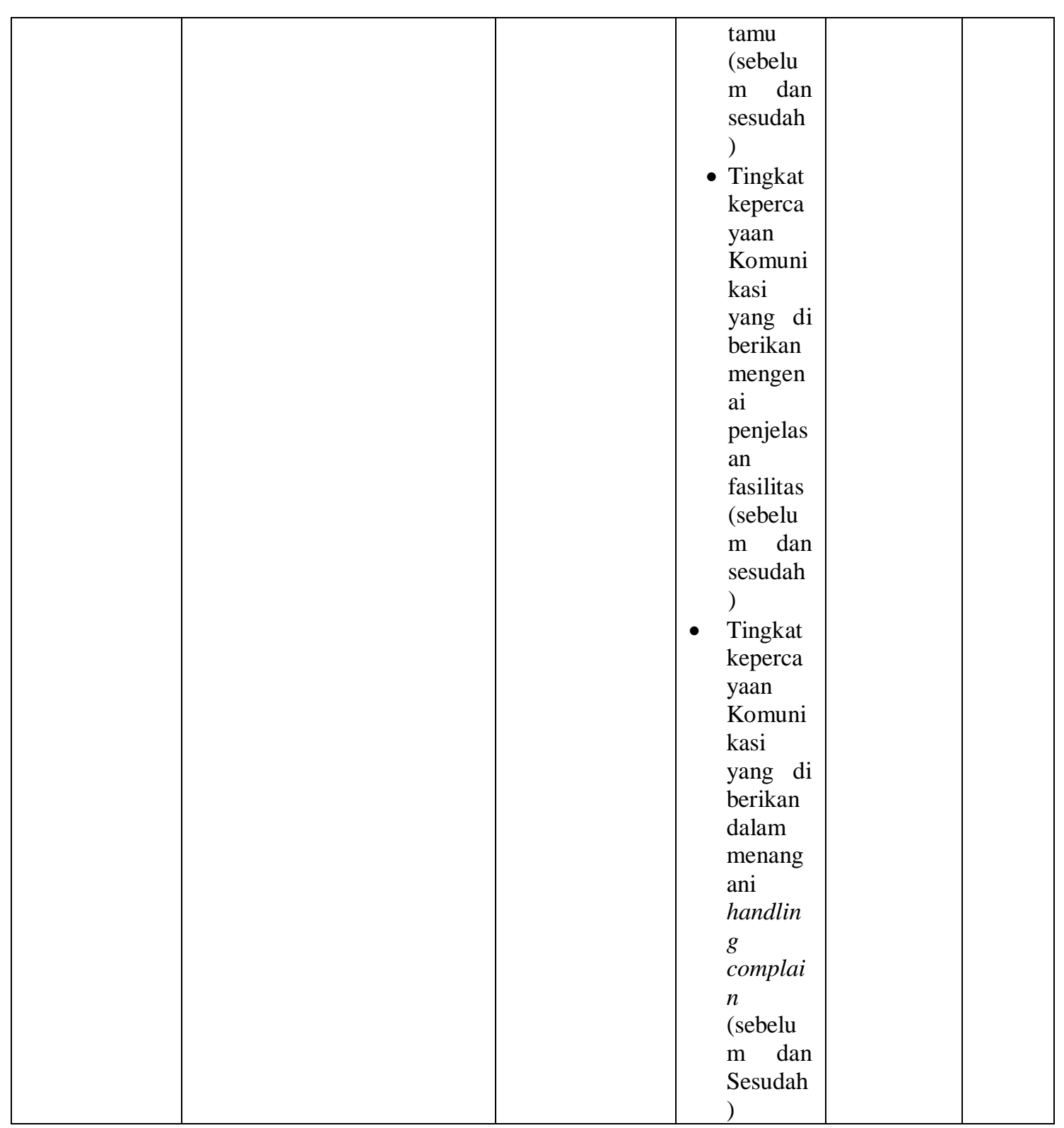

Sumber: Hasil pengolahan data, 2011

\subsection{Populasi dan Metode Penarikan Sampel} Populasi penelitian adalah tamu member baik Corporate. Tamu member corporate adalah tamu yang memiliki kartu member priority club dan menginap menggunakan nama perusahaan baik menggunakan corporate rate ataupun dalam rangka kegiatan perusahaan, sedangkan tamu member individu adalah tamu yang memiliki kartu priority club dan menginap atas nama pribadi. Pengambilan sampel ini digunakan taraf kesalahan sebesar $10 \%$. Dalam menentukan ukuran sampel (n) dan populasi $(\mathrm{N})$ yang telah ditetapkan, dapat digunakan dengan perhitungan Taro Yamane (Harun Al Rasyid, 1994:82), dengan rumus sebagai berikut :

$$
\mathrm{n}=\frac{\mathrm{N}}{\mathrm{N} .(\mathrm{d})^{2}+1}
$$

Keterangan:

$\mathrm{n}=$ Jumlah Sampel

$\mathrm{N}=$ Jumlah Populasi (832)

$\mathrm{d}=$ Derajat ketetapan $(10 \%)$

Berdasarkan perhitungan di atas, maka ukuran sampel minimal sebesar 89 responden. 
Menurut Sugiyono (2010:129) bahwa sebaiknya ada sampel yang ditambahkan sehingga pada penelitian ini ditentukan sampel berjumlah 100 responden. penelitian ini teknik yang digunakan adalah stratified random sampling.

\subsection{Prosedur Pengumpulan Data}

Pengumpulan data yang dilakukan penulis menggunakan teknik sebagai berikut.:
1. Wawancara
2. Observasi
3. Studi literatur
4. Angket/kuesioner

\subsection{Pengujian Hipotesis}

Teknik analisa data yang digunakan dalam penelitian ini adalah Regresi Linear berganda. Regresi Linier berganda digunakan untuk menentukan hubungan antara variabel independen yaitu Strategi repositioning terhadap variabel dependen $\mathrm{Y}$ yaitu kepercayaan, memprediksi nilai suatu variabel dari nilai variabel yang diketahui serta menentukan proporsi pengaruh variabel $\mathrm{X}$ terhadap variabel $\mathrm{Y}$ atau koefisien determinasi.

Langkah-langkah dalam teknis analisis data adalah sebagai berikut:

a. Method of Successive Interval (MSI)

Penelitian ini menggunakan data ordinal, semua data yang terkumpul terlebih dahulu ditransformasikan menjadi skala interval dengan menggunakan Method of Successive Interval menurut Harun $\mathrm{Al}$ Rasyid (1994:131). Langkah-langkah untuk melakukan transformasi data tersebut sebagai berikut:

1. Menghitung frekuensi (f) pada setiap pilihan jawaban, berdasarkan hasil jawaban responden pada setiap pertanyaan.

2. Berdasarkan frekuensi yang diperoleh untuk setiap pertanyaan, dilakukan perhitungan proporsi (p) setiap pilihan jawaban dengan cara membagi frekuensi dengan jumlah responden.

3. Berdasarkan proporsi tersebut, selanjutnya dilakukan perhitungan proporsi kumulatif untuk setiap pilihan jawaban.
4. Menentukan nilai batas $\mathrm{Z}$ untuk setiap pertanyaan dan setiap pilihan jawaban.

5. Menentukan nilai interval rata-rata untuk setiap pilihan jawaban melalui persamaan sebagai berikut:

Scale Value $=($ Dencity at LowerLimit $)$ -

(Dencity at UpperLimit)

(Area BelowUpperLimit) - (Area Below Lower Limit)

Data penelitian yang telah berskala interval selanjutnya akan ditentukan pasangan data variabel independen dengan variabel dependen serta akan ditentukan persamaan yang berlaku untuk pasangan-pasangan tersebut.

\section{b. Pengujian Asumsi Normalitas}

Langkah pertama untuk melakukan analisis regresi berganda adalah pengujian normalitas, seperti yang diungkapkan oleh Triton (2005:76), bahwa "Data sampel hendaknya memenuhi persyaratan distribusi normal". Data yang mengandung data ekstrim biasanya tidak memenuhi asumsi normalitas, untuk mendeteksi ini dilakukan dengan menggunakan normal probability plot. Berdasarkan metode ini dapat dikatakan berdistribusi normal apabila sebaran data terletak di sekitas garis lurus atau garis diagonal.

\section{c. Uji Asumsi Heteroskedastisitas}

Heteroskedastisitas adalah varian residual yang tidak konstan pada regresi sehingga akurasi hasil prediksi menjadi meragukan. Residu pada heteroskedastisitas semakin besar apabila pengamatan semakin besar. Suatu regresi dikatakan tidak terdeteksi heteroskedastisitas apabila diagram pencar residualnya tidak membentuk pola tertentu, dan pabila datanya berpencar disekitas angka nol pada sumbu Y.

\section{d. Uji Asumsi Multikolinearitas}

Uji multikolinearitas adalah situasi adanya korelasi yang kuat antara variabel bebas yang satu dengan variabel bebas yang lainnya dalam analisis regresi. Apabila dalam analisis terdeteksi multikolinearitas maka angka estimasi koefisien regresi yang didapatkan mempunyai nilai yang tidak sesuai dengan substansi, sehingga dapat menyesatkan interpretasi. Selain itu juga nilai standar error 
setiap koefisien regresi dapat menjadi tidak terhingga.

e. Analisis Regresi Linier Berganda

Variabel yang dianalisis adalah Variabel bebas yaitu strategi repositioning yang memiliki indikator brand logo $\left(\mathrm{X}_{1}\right)$, buildings renovation $\left(\mathrm{X}_{2}\right)$ dan staff performance $\left(\mathrm{X}_{3}\right)$, sedangkan variabel terikat adalah kepercayaan (Y). Langkah-langkah dalam perhitungan menggunakan teknik analisis regresi ganda adalah sebagai berikut:

1. Menentukan model persamaan regresi linear ganda $\mathrm{X}_{1}, \mathrm{X}_{2}, \mathrm{X}_{3}$ dan $\mathrm{Y}$. dilihat berdasarkan variabel yang akan diuji, maka pengujian statistik yang dilakukan menggunakan rumus menurut Sugiyono (2010:277) adalah:

$Y=a+b_{1} X_{1}+b_{2} X_{2}+b_{3} X_{3}$

Keterangan:

$\mathrm{Y}=$ Kepercayaan

$\mathrm{a}=$ Konstanta

$\mathrm{b}=$ Koefisien regresi

$\mathrm{X}_{1}=$ Brand logo

$\mathrm{X}_{2}=$ Building Renovation

$\mathrm{X}_{3}=$ Staff Performance

2. Interpretasi mengenai besarnya koefisien korelasi untuk mengetahui kuat pengaruh menurut Sugiyono (2010:250) dapat dilihat pada Tabel 3.7 sebagai berikut.

Tabel 3.8

Koefisien Korelasi

\begin{tabular}{|l|l|}
\hline $\begin{array}{l}\text { Besarnya } \\
\text { Nilai }\end{array}$ & Interpretasi \\
\hline $0,000-0,199$ & Sangat rendah \\
\hline $0,200-0,399$ & Rendah \\
\hline $0,400-0,599$ & Sedang \\
\hline $0,600-0,799$ & Kuat \\
\hline $0,800-1,00$ & Sangat kuat \\
\hline
\end{tabular}

Sumber : Sugiyono (2010:250)

3. Menguji signifikansi koefisien ganda secara simultan dengan membandingkan $F_{\text {hitung }}$ dengan $F_{\text {tabel }}$ menggunakan rumus:

$F_{\text {hitung }}=\frac{R^{2}(n-m-1)}{m\left(1-R^{2}\right)}$

Keterangan:

$\mathrm{F}_{\text {hitung }}=$ Nilai $\mathrm{F}$ yang dihitung

$\mathrm{R} \quad=$ Nilai koefisien korelasi ganda $\mathrm{m}=$ Jumlah variabel bebas

$\mathrm{n} \quad=$ Jumlah sampel

Kriteria pengujian:

Jika $F_{\text {hitung }} \geq F_{\text {tabel }}$ artinya signifikan

Jika $F_{\text {hitung }} \leq F_{\text {tabel }}$ artinya tidak signifikan

4. Menguji signifikansi koefisien korelasi ganda secara parsial dengan membandingkan $t_{\text {hitung }}$ dengan $t_{\text {tabel }}$ dengan menghitung nilai beta atau koefisien jalur yaitu koefisien regresi yang distandarkan untuk mengetahui besarnya kontribusi masing-masing variabel bebas terhadap variabel terikat dengan rumus:

$\rho_{y k x}=\frac{S k}{S r}\left(b_{k}\right)$

Keterangan :

$\rho_{\mathrm{ykx}}=$ Koefisien regresi yang distandarkan

Sk = Standar deviasi variabel bebas

$\mathrm{Sr}=$ Standar deviasi variabel terikat

$b_{k}=$ Koefisien regresi variabel bebas yang terdapat dalam persamaan regresi

Secara statistik, hipotesis yang akan di uji dalam rangka pengambilan keputusan penerimaan atau penolakan dapat ditulis sebagai berikut:

Secara simultan:

Ho:PYX =0: tidak berpengaruh strategi repositioning terhadap kepercayaan

Ho: $\mathrm{PYX} \neq 0$ : terdapat pengaruh strategi repositioning terhadap kepercayaan

Secara parsial:

Ho:PYX =0: tidak terdapat pengaruh antara strategi repositioning Holiday Inn Bandung terhadap kepercayaan.

Ho: $\mathrm{PYX} \neq 0$ : terdapat pengaruh antara strategi repositioning Holiday Inn Bandung terhadap kepercayaan.

Ho: $\mathrm{PYX}_{1.1}=0$ : tidak terdapat pengaruh antara brand logo Holiday Inn Bandung terhadap kepercayaan.

Ho: $\mathrm{PYX}_{1.1} \neq 0$ : terdapat pengaruh antara brand $\operatorname{logo}$ Holiday Inn Bandung terhadap kepercayaan.

Ho:PYX 1.2 =0: tidak terdapat pengaruh antara building renovation Holiday Inn Bandung terhadap kepercayaan. 
Ho: $\mathrm{PYX}_{1.2} \neq 0$ : terdapat pengaruh antara building renovation Holiday Inn Bandung terhadap kepercayaan. Ho: PYX $_{1.3} \quad=0$ : tidak terdapat pengaruh antara staff performance Holiday Inn Bandung terhadap kepercayaan.

Ho: $\mathrm{PYX}_{1.3} \neq 0$ : terdapat pengaruh antara staff performance Holiday Inn Bandung terhadap kepercayaan.

Sedangkan hipotesis yang dapat digambarkan pada penelitian ini adalah sebagai berikut.

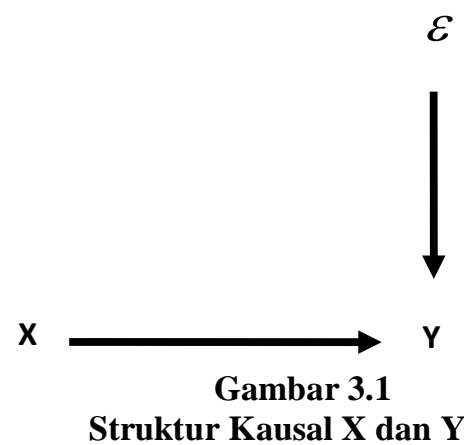

Keterangan :

$\mathrm{X}$ : Variabel strategi repositioning

$\mathrm{Y}$ : Variabel kepercayaan

$\varepsilon \quad$ : Residu (variabel lain diluar variabel $\mathrm{X}$ yang berpengaruh) ke arah variabel akibat dinyatakan oleh besarnya nilai numeric dari variabel eksogus.

\section{HASIL PENELITIAN DAN} PEMBAHASAN

4.1 Tanggapan Tamu Member terhadap Strategi Repositioning

Berdasarkan hasil pengolahan data varibel $\mathrm{x}$, diperoleh rekapitulasi tanggapan tamu member mengenai strategi repositioning yang terdapat pada Tabel 4.4 berikut:

TABEL 4.4

REKAPITULASI TANGGAPAN TAMU

MEMBER MENGENAI STRATEGI

REPOSITIONING HOLIDAY INN

BANDUNG

\begin{tabular}{|l|l|c|c|c|c|}
\hline \multirow{2}{*}{ No } & \multirow{2}{*}{ Dimensi } & \multicolumn{2}{|c|}{ Corporate } & \multicolumn{2}{c|}{ Individu } \\
\cline { 3 - 6 } & & $\begin{array}{c}\text { Sebelu } \\
\text { m }\end{array}$ & $\begin{array}{c}\text { Sesud } \\
\text { ah }\end{array}$ & $\begin{array}{c}\text { Sebelu } \\
\text { m }\end{array}$ & $\begin{array}{c}\text { Sesud } \\
\text { ah }\end{array}$ \\
\hline 1 & Brand Logo & 2.77 & 2.53 & 2.74 & 2.59 \\
\hline 2 & $\begin{array}{l}\text { Building } \\
\text { Renovation }\end{array}$ & 2.66 & 2.52 & 2.73 & 2.59 \\
\hline
\end{tabular}

\begin{tabular}{|l|l|l|l|l|l|}
\hline 3 & $\begin{array}{l}\text { Staff } \\
\text { Performance }\end{array}$ & 2.65 & 2.38 & 2.73 & 2.49 \\
\hline
\end{tabular}

Sumber: Hasil pengolahan data 2011

Berdasarkan Tabel 4.4 dapat diketahui bahwa sesudah diadakannya strategi repositioning, dimensi yang memiliki penilaian tertinggi bagi tamu member corporate yaitu brand logo sebesar $50.6 \%$. Hal ini dikarenakan logo merupakan komponen perusahaan yang dapat dilihat oleh siapapun sebelum tamu memasuki gedung dan memperhatikan seragam karyawan. Logo merupakan salah satu pencerminan karakteristik dan ciri dari perusahaan. Logo dapat dijadikan alat komunikasi bagi perusahaan dalam menarik perhatian dari tamu untuk menginap. Sedangkan menurut tamu member individu penilaian tertinggi di dapat melalui brand logo dan building renovation sebesar $51,8 \%$. Perubahan beberapa fasilitas gedung serta penambahan pada awalnya menjadi salah satu daya tarik yang membuat tamu member menginap di Holiday Inn Bandung. Tamu member yang menginap pada mulanya ingin mencoba serta merasakan perbedaan antara suasana dan fasilitas yang sudah terbiasa digunakan di Holiday Inn Bandung dengan suasana serta fasilitas yang baru.

Sedangkan untuk dimensi dengan penilaian terendah sesudah diadakan perubahan baik menurut tamu member corporate maupun tamu member individu yaitu staff performance sebesar $2.38 \%$ untuk tamu member corporate dan $2.49 \%$ untuk jenis tamu member individu. Hal ini dikarenakan warna apapun yang digunakan sebagai seragam karyawan akan mencerminkan suasana yang berbeda, maka adanya perubahan warna akan berpengaruh terhadap penilaian. Hal terpenting dalam penilaian karyawan adalah sikap saat melakukan pelayanan kepada tamu.

\subsection{Tanggapan Tamu Member terhadap Kepercayaan}

Berdasarkan hasil pengolahan data varibel $\mathrm{y}$, diperoleh rekapitulasi tanggapan tamu member baik corporate maupun individu mengenai kepercayaan terhadap Holiday Inn Bandung seperti yang terdapat pada Tabel 4.5 berikut: 


\section{TABEL 4.5 \\ REKAPITULASI TANGGAPAN TAMU MEMBER MENGENAI KEPERCAYAAN TERHADAP HOLIDAY INN BANDUNG

\begin{tabular}{|l|l|l|l|l|l|}
\hline No & Dimensi & \multicolumn{2}{|l|}{ Corporate } & \multicolumn{2}{|l|}{ Individu } \\
\cline { 3 - 6 } & $\begin{array}{l}\text { Sebelu } \\
\text { m }\end{array}$ & $\begin{array}{l}\text { Sesuda } \\
\text { h }\end{array}$ & $\begin{array}{l}\text { Sebel } \\
\text { um }\end{array}$ & $\begin{array}{l}\text { Sesud } \\
\text { ah }\end{array}$ \\
\hline 1 & Kepercayaan & 2.51 & 2.62 & 2.66 & 2.69 \\
\hline
\end{tabular} \\ Sumber: Hasil pengolahan data 2011 \\ Berdasarkan Tabel 4.5 dapat diketahui bahwa sesudah diadakannya strategi repositioning, dimensi kepercayaan yang memiliki penilaian bagi tamu member corporate sebesar 52,4\% lebih besar dibandingkan skor sebelum diadakan perubahan sebesar $50,2 \%$. Hal ini kepercayaan tamu member corporate lebih bertambah seiring dengan keseriusan perubahan yang dilakukan untuk dapat lebih menarik perhatian tamu. Sedangkan menurut tamu member individu penilaian didapat sebesar 2.69. Hal ini dikarenakan rasa tanggung jawab karyawan yang lebih baik sehingga tamu merasa nyaman untuk menginap saat melakukan perjalanan berlibur serta menginap. \\ Kondisi ini dikarenakan perubahan yang terjadi membuat adanya keyakinan dan kepercayaan di benak tamu member yang menginap bahwa Holiday Inn Bandung melakukan strategi tersebut dengan maksud untuk memberikan fasilitas serta pelayanan yang lebih baik dari sebelumnya serta memperkuat positioning perusahaan sebagai hotel bisnis terbaik yang selalu dicintai oleh tamu. Hermawan Kartajaya (2004:60) mengemukakan bahwa, "Membangun positioning baru tak lain adalah soal bagaimana kita mencari kepercayaan. Positioning menyangkut penciptaan 'being' di dalam benak konsumen dan mengarahkan konsumen dengan penuh kredibilitas".}

\subsection{Pengaruh Strategi Repositioning Holiday Inn Bandung Terhadap Kepercayaan \\ a) Hasil Uji Asumsi Normalitas}

Langkah pertama yang dilakukan untuk pengujian pengaruh menggunakan analisis regresi adalah pengujian asumsi normalitas. Uji normalitas dimaksudkan untuk mengetahui apakah residual yang diteliti berdistribusi normal atau tidak. Nilai residual berdistribusi normal merupakan suatu kurva berbentuk lonceng yang kedua sisinya melebar sampai tidak terhingga. Jika sebaran data mengikuti sebaran normal, maka populasi dari mana data diambil berdistribusi normal dan akan dianalisis menggunakan analisis parametrik.

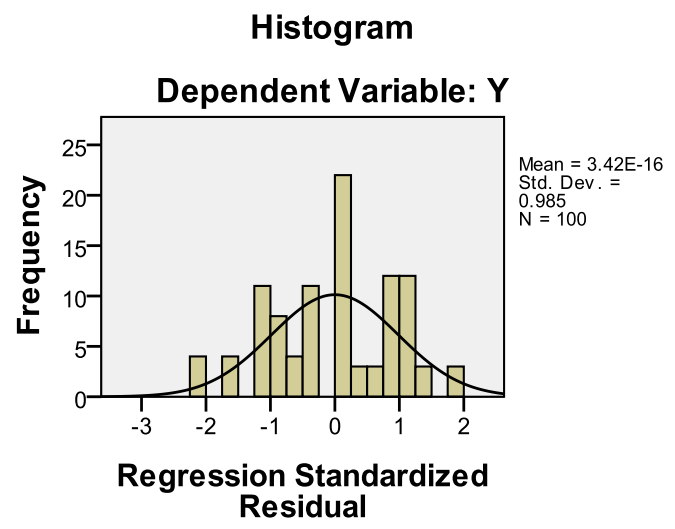

Sumber : Hasil Pengolahan data 2011

GAMBAR 4.24

HISTOGRAM DEPENDENT VARIABLE KEPERCAYAAN TAMU MEMBER TERHADAP HOLIDAY INN BANDUNG

Gambar 4.24 merupakan histogram kepercayaan tamu member corporate terhadap kepercayaan. Berdasarkan gambar tersebut dapat dikatakan bahwa model berdistribusi normal karena kurva membetuk lonceng. Pengujian ini dilakukan dengan menggunakan normal probability plot. Gambar 4.25 di bawah ini menggambarkan normal probability plot yang digunakan untuk mendeteksi apakah data yang digunakan berdistribusi normal atau tidak.

\section{b) Uji Asumsi Heteroskedastisitas}

Heteroskedastisitas adalah varian residual yang tidak konstan pada regresi sehingga akurasi hasil prediksi menjadi meragukan. Residu pada heteroskedastisitas semakin besar apabila pengamatan semakin besar. Menurut Wahid Sulaiman (2004:106), suatu regresi dikatakan tidak terdeteksi heteroskedastis apabila penyebaran nilai-nilai residual terhadap harga-harga prediksi tidak membentuk suatu pola tertentu (meningkat atau menurun). Suatu regresi dikatakan tidak terdeteksi Heteroskedastisita apabila diagram pencar residualnya tidak membentuk pola tertentu, dan apabila datanya berpencar disekitar angka 35 (pada sumbu Y). 


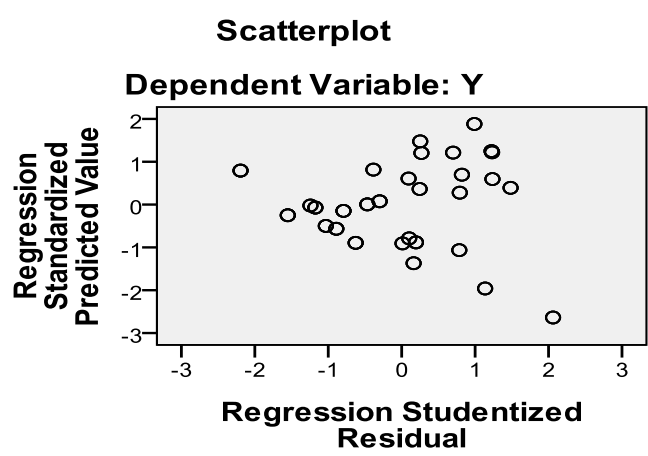

Sumber : Hasil Pengolahan data 2011

GAMBAR 4.25

\section{HASIL UJI HETEROKEDASTISITAS}

Berdasarkan Gambar 4.25 dapat diketahui bahwa tidak terjadi heteroskedastisitas sebab tidak ada pola yang jelas serta titik-titik menyebar di atas dan di bawah angka 0 pada sumbu $\mathrm{Y}$. sehingga dapat dikatakan uji heteroskedastisitas telah terpenuhi.

\section{c) Hasil Uji Asumsi Multikolinearitas}

Multikolinearitas artinya terdapat hubungan linear yang sempurna atau pasti diantara beberapa atau semua variabel yang menjelaskan dari model regresi, yaitu terdapatnya lebih dari satu hubungan linear pasti. Berdasarkan teori tersebut, maka dalam penelitian ini terdapat korelasi yang rendah antara variabel bebas dapat dijelaskan. Untuk mengetahui terjadinya multikolinearitas dalam penelitian ini digunakan matriks korelasi yang dihitung dengan bantuan paket program SPSS 18.0 pada tabel 4.6 berikut:

\section{TABEL 4.6}

MATRIK KORELASI ANTAR VARIABEL BEBAS

\begin{tabular}{|l|l|l|l|l|l|}
\hline \multicolumn{5}{|c|}{ Correlations } & \\
\hline & & $\begin{array}{l}\text { Keper } \\
\text { cayaa } \\
\text { n }\end{array}$ & $\begin{array}{l}\text { Bran } \\
\text { d } \\
\text { Logo }\end{array}$ & $\begin{array}{l}\text { nuildi } \\
\text { Lenov } \\
\text { Renov } \\
\text { ation }\end{array}$ & $\begin{array}{l}\text { Staff } \\
\text { Perfor } \\
\text { mance }\end{array}$ \\
\hline $\begin{array}{l}\text { Pearso } \\
\text { n } \\
\text { Correl } \\
\text { ation }\end{array}$ & $\begin{array}{l}\text { Keperc } \\
\text { ayaan }\end{array}$ & 1.000 & .690 & .267 & .606 \\
\cline { 2 - 6 } & $\begin{array}{l}\text { Brand } \\
\text { Logo }\end{array}$ & .690 & 1.00 & .317 & .666 \\
\cline { 2 - 3 } & $\begin{array}{l}\text { Buil } \\
\text { g } \\
\text { Renova } \\
\text { tiom }\end{array}$ & .267 & .317 & 1.000 & .282 \\
\hline
\end{tabular}

\begin{tabular}{|l|l|l|l|l|l|}
\hline $\begin{array}{l}\text { Staff } \\
\text { Perfor } \\
\text { mance }\end{array}$ & .606 & .666 & .282 & 1.000 \\
\hline
\end{tabular}

Sumber : Hasil Pengolahan data 2011

Berdasarkan Tabel 4.6 menunjukkan bahwa korelasi antar variabel bebas tidak terdapat nilai yang melebihi 0.80 (semua kurang dari 0.80), dengan demikian tidak terjadi multikolinearitas, dengan mengacu pada Gujaratai (2003:362) mengemukakan bahwa, "Apabila korelasi antar variabel bebas tidak terdapat nilai lebih dari 0.80 maka tidak terjadi multikolinearitas".

\subsubsection{Pengujian Hipotesis Secara Simultan (Uji F)}

Pengujian signifikasi pada analisis regresi dapat digunakan uji $\mathrm{F}$, untuk lebih jelasnya mengenai output ANOVA dapat dilihat pada Tabel 4.7

TABEL 4.7

\section{HASIL PENGUJIAN HIPOTESIS} SECARA SIMULTAN

\begin{tabular}{|l|l|l|l|l|l|}
\hline \multicolumn{7}{|c|}{ ANOVAb } \\
\hline & $\begin{array}{l}\text { Sum of } \\
\text { Squares }\end{array}$ & Df & $\begin{array}{l}\text { Mean } \\
\text { Squar }\end{array}$ & F & Sig. \\
\hline $\begin{array}{l}\text { Regressio } \\
\text { n }\end{array}$ & 1417,482 & 3 & $\begin{array}{l}472,4 \\
94\end{array}$ & $\begin{array}{l}34,0 \\
40\end{array}$ &, $000^{\text {a }}$ \\
\hline Residual & 1332,540 & 97 & $\begin{array}{l}13,88 \\
1\end{array}$ & & \\
\hline Total & 2750,023 & 99 & & & \\
\hline
\end{tabular}

a. Predictors: (Constant), Brand logo, Building renovation,Staff performance

b. Dependent Variable: Kepercayaan

Sumber : Hasil Pengolahan data 2011

Berdasarkan Tabel 4.7 diperoleh nilai $\mathrm{F}_{\text {hitung }}=34.040$ dengan nilai signifikansinya 0,000. Nilai signifikansi lebih kecil dari taraf signifikansi $10 \%$, sehingga jelas H0 ditolak dan Ha diterima. Dengan nilai signifikansi 0,000 nilai signifikansi lebih kecil dari taraf signifikansi $10 \%$ maka regresi dapat digunakan untuk memprediksi kepercayaan atau variabel repositioning berpengaruh terhadap kepercayaan pada taraf kepercayaan $90 \%$. berikut:

Hipotesis dalam penelitian ini sebagai

Ha $\neq 0$, Terdapat pengaruh signifikan antara strategi repositioning terhadap kepercayaan. Hal ini dapat dibuktikan 
dengan kepercayaan dari tamu member terhadap Holiday Inn Bandung yang tetap memilih menginap serta melakukan kegiatan-kegiatan bisnis seperti meeting ataupun seminar. Selain itu mencoba menjalankan komunikasi dengan perubahan logo yang lebih menarik serta penambahan kamar dan perubahan desain gedung sehingga membuat tamu lebih merasa nyaman. Hal ini dilakukan agar dapat lebih bersaing dengan hotel-hotel lain yang sedang berkembang pesat, serta menciptakan ciri dari Holiday Inn Bandung dibandingkan dengan hotel pesaing lainnya.

Muzzellec \& Lambkin (2006:806) mengemukakan bahwa alasan utama meneliti strategi repositioning dimaksudkan untuk mengembangkan beberapa kombinasi perubahan yang dilakukan untuk mendeferensiasikan posisi baru yang perusahaan miliki di benak stakeholder serta konsumen. Apabila kombinasi perubahan yang dilakukan tepat dan berhasil maka akan berdampak pada kepercayaan tamu untuk tetap memilih serta menginap di Holiday Inn Bandung.

\subsubsection{Pengujian Hipotesis Secara Parsial (Uji t)}

\section{TABEL 4.8}

HASIL PENGUJIAN SECARA PARSIAL (UJI T)

\begin{tabular}{|c|c|c|c|c|c|}
\hline \multicolumn{6}{|c|}{ Coefficients } \\
\hline \multirow[b]{2}{*}{ Model } & \multicolumn{2}{|c|}{$\begin{array}{l}\text { Unstandar } \\
\text { dized } \\
\text { Coefficient } \\
\text { s }\end{array}$} & \multirow{2}{*}{$\begin{array}{l}\text { Standard } \\
\text { ized } \\
\text { Coefficie } \\
\text { nts } \\
\\
\text { Beta }\end{array}$} & \multirow[b]{2}{*}{$\mathrm{t}$} & \multirow[b]{2}{*}{$\begin{array}{l}\mathrm{Si} \\
\mathrm{g} .\end{array}$} \\
\hline & B & \begin{tabular}{|l} 
Std. \\
Erro \\
$\mathrm{r}$ \\
\end{tabular} & & & \\
\hline \begin{tabular}{l|l}
1 & (Constan \\
t)
\end{tabular} & $\begin{array}{l}4,48 \\
9\end{array}$ & $\begin{array}{l}1,92 \\
3\end{array}$ & & $\begin{array}{l}2,3 \\
34\end{array}$ & $\begin{array}{l}.0 \\
22\end{array}$ \\
\hline $\begin{array}{l}\text { (X1 } \\
\text { Brand } \\
\text { Logo }\end{array}$ & $\begin{array}{l}1.25 \\
3\end{array}$ & .240 & .506 & $\begin{array}{l}5,2 \\
28\end{array}$ & $\begin{array}{l}.0 \\
00\end{array}$ \\
\hline $\begin{array}{l}\text { ( } \\
\text { Building } \\
\text { Renovati } \\
\text { on }\end{array}$ & .084 & .195 & .033 & $\begin{array}{l}.43 \\
2\end{array}$ & $\begin{array}{l}.6 \\
66\end{array}$ \\
\hline
\end{tabular}

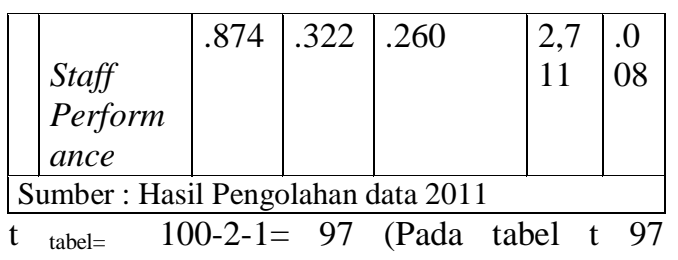
mempunyai nilai 1,67 )

Untuk menguji dimensi dari variabel repositioning maka dapat digunakan distribusi t-hitung, dapat dijelaskan sebagai berikut:

1. Hasil uji t parsial dapat diketahui bahwa nilai $\mathrm{t}$ hitung untuk dimensi brand logo (X1) sebesar 5,228 lebih besar dari 1,67, ini berarti terdapat pengaruh yang signifikan antara dimensi brand logo dengan kepercayaan.

2. Hasil uji t parsial dapat diketahui bahwa nilai t hitung untuk dimensi building renovation (X2) sebesar 0,432 lebih kecil dari 1,67, ini berarti bahwa tidak terdapat pengaruh yang signifikan antara dimensi building renovation dengan kepercayaan. Tidak signifikannya pada dimensi building renovation dikarenakan tamu lebih merasa nyaman dengan tampilan gedung serta ketersediaan fasilitas sebelum diadakan perubahan. Perubahan pada gedung sedikit banyak membuat tamu merasa bingung. Sehingga tamu member yang menginap di Holiday Inn Bandung merasa lebih nyaman dengan letak fasilitas sebelum adanya perubahan. Namun demikian perubahan yang dilakukan merupakan salah satu langkah terbaik yang dilakukan Holiday Inn Bandung.

3. Hasil uji t parsial dapat diketahui bahwa nilai t hitung untuk dimensi staff performance (X3) sebesar 2,711 lebih besar dari 1,67, ini berarti terdapat pengaruh yang signifikan antara dimensi staff performance dengan kepercayaan.

\subsubsection{Besarnya Pengaruh Repositioning terhadap Kepercayaan}

Untuk mengetahui seberapa kuat hubungan dan seberapa besar pengaruh strategi repositioning yang terdiri brand logo (X1) dan staff performance (X3) dapat dilihat 
melalui nilai koefisien korelasi dan determinasi.

TABEL 4.9

\section{OUTPUT PENGARUH STRATEGI REPOSITIONING HOLIDAY INN BANDUNG TERHADAP KEPERCAYAAN}

\begin{tabular}{|c|c|c|c|c|}
\hline \multicolumn{5}{|c|}{ Model Summary } \\
\hline Model & $\mathrm{R}$ & $\begin{array}{l}\mathrm{R} \\
\text { Square }\end{array}$ & $\begin{array}{l}\text { Adjusted } \\
\text { R } \\
\text { Square }\end{array}$ & $\begin{array}{l}\text { Std. Error } \\
\text { of the } \\
\text { Estimate }\end{array}$ \\
\hline 1 & .717 & .515 & .504 & 3.71002 \\
\hline
\end{tabular}

a. Predictors: (Constant), Brand logo, Staff performance

b. Dependent Variable: Kepercayaan

Sumber : Hasil Pengolahan data 2011

Berdasarkan Tabel 4.9 diperoleh nilai koefisien korelasi strategi repositioning dengan kepercayaan sebesar 0,717. Bila korelasi tersebut diinterpretasikan pada tabel korelasi maka hubungan antara strategi repositioning terhadap kepercayaan memiliki hubungan yang kuat sesuai dengan klasifikasi koefisien korelasi menurut Sugiyono (2008:250). Berdasarkan hasil perhitungan, nilai koefisien determinasi adalah 0,515 atau $51,5 \%$. Hal ini menunjukkan bahwa secara bersama-sama variabel repositioning memberikan kontribusi $51,5 \%$ terhadap kepercayaan sedangkan $48,5 \%$ dipengaruhi oleh faktor lain.

Hal ini sesuai dengan pernyataan yang dikemukakan oleh Hermawan Kartajaya (2008:57) bahwa, "Repositioning adalah bagaimana perusahaan membangun janji, kepercayaan dan keyakinan kepada konsumen serta positioning menjadi penentu penting bagi konsumen pada saat memutuskan untuk membeli". Secara lengkap pengaruh strategi repositioning terhadap kepercayaan tersaji pada gambar berikut.

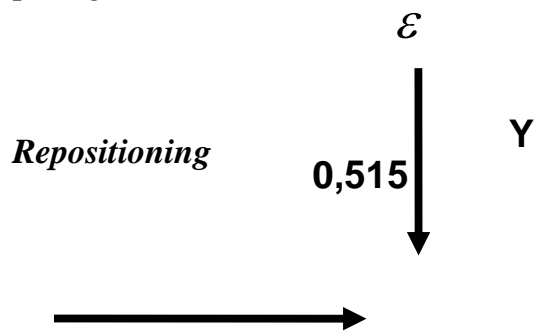

Sumber : Hasil Pengolahan data 2011

GAMBAR 4.26 SRTUKTUR KAUSAL HIPOTESIS

\subsubsection{Model Persamaan Regresi Pengaruh Strategi Repositioning Terhadap Kepercayaan}

Hasil analisa data dengan bantuan pengolahan komputer berdasarkan perhitungan SPSS 18 for windows diperoleh persamaan regresi sederhana sebagai berikut :

$Y=a+b_{1} X_{1}+b_{3} X_{3}$

Berdasarkan hasil pengolahan data maka persamaan regresi untuk strategi repositioning adalah:

$Y=4,489+1,253(X 1)+0,874(X 3)$

Dimana,

$\mathrm{Y}=$ Kepercayaan

$\mathrm{X} 1=$ Brand $\log o$

$\mathrm{X} 3$ = Staff performance

Berdasarkan persamaan di atas, maka nilai koefisien regresi dapat dijelaskan sebagai berikut:

1. Brand logo $\left(\mathrm{X}_{1}\right)=1,253$ maka perubahan brand logo sebesar satu satuan akan menimbulkan kontribusi sebesar $4,489+1,253(1)=5,742$ terhadap kepercayaan. Jika brand logo dinaikan sebesar satu-satuan maka kepercayaan akan meningkat sebesar 1,253.

2. Staff performance $\left(\mathrm{X}_{3}\right)=0,874$ maka perubahan staff performance sebesar satu satuan akan menimbulkan kontribusi sebesar 4,489+0,874(1) $=5,363$ terhadap kepercayaan. Jika staff performance dinaikan sebesar satu-satuan maka kepercayaan akan meningkat sebesar 0,874 .

Dimensi building renovation tidak dimasukan dalam model persamaan regresi dikarenakan nilai $\mathrm{t}$ lebih kecil dari sig. sehingga tidak signifikan. Setiap indikator repositioning yang diteliti menunjukan bahwa indikator dimensi brand logo memberikan pengaruh yang sangat kuat, sesuai dengan pernyataan Hanafiah dalam jurnal manajemen (2004) bahwa, "Dalam bisnis perusahaan, logo didalamnya terkandung janji perusahaan kepada konsumen untuk memberikan manfaat, keistimewaan dan layanan tertentu". Logo selalu dijadikan salah satu alat komunikasi oleh perusahaan untuk menyampaikan tujuan perusahaan tersebut.

Sedangkan staff performance di nilai memberikan pengaruh yang kuat terhadap kepercayaan. Sesuai dengan pernyataan yang dikemukakan oleh Kotler (2010:283) bahwa, 
"Seorang karyawan hotel harus menjadi seseorang yang mempunyai jiwa hospitality tinggi pada saat berinteraksi”. Karyawan yang ramah dan mempunyai perilaku serta penampilan yang baik dengan tamu akan mampu menciptakan kepercayaan sehingga membuat tamu tersebut kembali menginap.

\section{KESIMPULAN}

1. Gambaran mengenai strategi repositioning yang dilakukan oleh Holiday Inn Bandung mendapat penilaian yang cukup baik dari tamu member yang menginap. Brand logo merupakan dimensi yang dinilai memiliki nilai tertinggi dalam meningkatkan kepercayaan. Logo dapat menjadi alat komunikasi yang digunakan oleh perusahaan. Salah satunya industri perhotelan, dengan logo hotel dapat menyampaikan tujuan perusahaan. Sedangkan dimensi building renovation tidak memiliki pengaruh. Hal ini dikarenakan adanya ketidaknyamanan serta kebingunan terhadap beberapa perubahan letak fasilitas sehingga tamu kembali beradaptasi dengan suasana yang baru. Selain itu sebagian tamu member yang menginap serta mengisi kuesioner adalah tamu yang kurang dari 3 kali menginap kembali setelah dilakukannya perubahan. Sehingga tamu masih butuh waktu untuk beradaptasi dengan suasana serta letak fasilitas yang baru, bahkan sebagian dari tamu member mengutarakan bahwa tamu tersebut lebih menyukai desain dan letak fasilitas Holiday Inn Bandung sebelum dilakukannya perubahan karena lebih mudah dijangkau. Namun demikian perubahan yang dilakukan merupakan salah satu langkah terbaik yang dilakukan Holiday Inn Bandung untuk tetap menjadi hotel bisnis yang terbaik.

2. Gambaran mengenai tingkat kepercayaan terhadap Holiday Inn Bandung mendapatkan peningkatan yang baik. Penilaian tertinggi diantara variabel kepercayaan yaitu keyakinan pelayanan dan tanggung jawab yang diberikan karyawan Holiday Inn Bandung kepada tamu member.

3. Strategi repositioning yang terdiri dari brand $\operatorname{logo}$ dan staff performance memiliki pengaruh yang cukup baik terhadap kepercayaan tamu member kepada Holiday Inn Bandung dengan nilai pengaruh yang tinggi. Sedangkan building renovation di nilai tidak memiliki pengaruh karena adanya ketidaknyamanan di benak tamu member.

\section{DAFTAR PUSTAKA}

Aaker, David. A. 2006. Marketing Research . John Wiley \& Sons.

Ali, Hasan. 2008. Marketing. Media Presindo.

Andrew T. Kaczynski and John L. Crompton. 2004, An operational tool for determining the optimum repositioning strategy for leisure service departments. Managing Leisure 9, 127144, July 2004.

Aras, Gor, Dr, Banum Dincer.2010.Rethinking Brands in the Emerging Financial Markets. Journal of Economi.

Astri, Dhiah, Maharani. 2010. Analisis Pengaruh Kepercayaan dan Kepuasan Terhadap Loyalitas Nasabah Tabungan Bank Mega Semarang.

Aydin, Serkan, dan Ozer, Gokhan. 2005. "Customer loyalty and the effect of switching cost as a moderator variable in the Turkish mobile phone market". European Journal of Marketing, 23:89103.

Awa, O, Hart, M.Sc, MBA.2010. Repositioning the Non-Incremental Changes and Business Strategic Windows Correlates Vol 5 No 2.

Brackenburry, M. 2007. Promoting Destinations Opportunities and Threats. Destination Marketing and Management-Designing and Repositioning Tourism Products. Venezia.

David, Fred, R. 2009. Manajemen Strategi Pemasaran Dalam Industri. Universitas Sumatra Utara.

Djaslim, Saladin. 2003. Manajemen Pemasaran. Linda Karya Bandung.

Fandy, Tjiptono. 2007. Service, Quality Satisfaction. Yogyakarta: Andi.

French, Y. 2007. The Communication and PR Strategies For Mature Destinations Repositioning Themselves. Venezia.

Gujaratai. 2006. "Essensial Econometrics, 3. New York: McGraw Hill. 
Harun, Al, Rasyid. 1994. Teknik Penarikan Sampel dan Penyusunan Skala. Universitas Padjajaran Bandung.

Hermawan, Kertajaya. Et.al. 2008. Marketing, Diferensiasi, Positioning. Jakarta: PT. Gramedia Pustaka Utama

Herry, Pintardi, Chandra. 1999. Faktor-Faktor Strategi Positioning Dalam Pemasaran Realestat. pp 114-124:Surabaya.

Husein, Umar. 2006. Metode Penelitian dan Aplikasi dalam Pemasaran. Jakarta: PT. Gramedia Pustaka Umum.

Kotler, Philip. 2001. Marketing Management: Analysis, Planning, Implementation, and Control, 9th Ed., Englewood Cliffs, NJ: Prentice Hall, Inc.

Kotler, Philip dan Bowen, T, Jhon. 2010. Marketing For Hospitality and Tourism. Pearson Prentice Hall.

Kotler, Philip, dan Kevin Keller. 2009. Manajemen Pemasaran, Edisi Kedua Belas Jilid 1. Indonesia: PT. Indeks.

Lau, G.T. dan Lee, S.H., 1999. "Consumers Trust In a Brand and the Link to Brand Loyalty“, Journal of Market Focused Management, Vol 4,pp 341-370.

Lui, S, Steven, and Ngo, Yue, Hang. 2004. The Role of Trust and Contractual Safeguards on Coorperation in Nonequity Alliances. Journal of Management,pp 30-471.

Maholtra, Naresh K. 2005. Riset Pemasaran, Pendekatan Terapan edisi ke-4 Jilid 1. Jakarta:PT. Indeks Gramedia.

Michael, Adiwijaya. 2007. Analisa Strategi Reposisi Merek Dalam Persaingan Pasar. Jurnal Manajemen Pemasaran Vol 2 No 2,pp 66-72.

Morgan, R.M, and Hunt, S.D. 1994."The Commitment-Trust Theory of Relationship Marketing“. Journal of Marketing, Vol.58, July, pp.20-38.

Morrisson, Alstair.2006. Hospitality and Travel Marketing. Thomson Learning. Columbia.

Muzzellec, M.C \& Lambkin.2006. Positioning: Teori, Trend and Strategi. Journal of Marketing Management.

Poerwanto. 2004. Pengembangan Kualitas Dalam Industri Jasa. Jurnal Manajemen. Jakarta.

Schiffman, Lg \& Kanuk, L1.2000. Consumer Behaviour. 7 ed. London. Pretience Hall.
Shelmi. 2008. Journal Destination Brand: Membangun Keunggulan Bersaing, Vol 4 No 2.

Sugiyono. 2010. Metodologi Penelitian Bisnis. Bandung: Alfabeta.

-----------. 2006. Metodologi Penelitian Statistika. Bandung: Alfabeta.

-----------. 2008. Metodologi Penelitian Kualitatif dan Kuantitatif. Bandung: Alfabeta.

Suharsimi, Arikunto. 2009. Prosedur Penelitian Suatu Pendekatan Praktis. Yogyakarta: Rineka Cipta.

Tatang, Kusmayadi. 2007. Pengaruh Relationship Quality Terhadap Loyalitas Nasabah Tabungan. STIE STAN Indonesia Mandiri.

Trout, Jack. 2010. Rpositioning. 2010. Jakarta:PT. Elex Media Komputindo.

Uma, Sekaran. 2000 Research Method For Business. Third Edition. Jhon Wiley \& Sons. Inc: USA.

Vanessa, Gaffar. 2007. CRM dan MPR Hotel. Bandung:Alfabeta.

Wijaya, Serly dan Thio, Sienny, 2007. Implementasi Membership Card dan Pengaruhnya Dalam Meningkatkan Loyalitas Pengunjung Restoran di Surabaya. Fakultas Ekonomi Universitas Kristen Petra

Yakimov, Raisa and Michael Beverland. 2006. Repositioning Capabilities: Enablers of Ongoing Brand Management. Research Monash University.

\section{Situs dan Jurnal}

www.google.com/usulibrary/repositioning www.wikipedia.org/wiki/Repositioning www.wordpress.com www.ihg_annual_report_2010 www.ihg_annual_review_2010 
Gina Shesarria, Gitasiswhara

Tourism and Hospitality Essentials (THE) Journal, Vol.II, No.2, 2012 -362 